\title{
Improving Human Resource Through School-Industry Cooperation Program to Face Industry 4.0
}

\author{
Elis Nur Unsudah ${ }^{1^{*}}$, Agus Hery Supadmi Irianti ${ }^{2^{*}}$ \\ ${ }^{I}$ Faculty of Engineering Vocational Education Study Program 1, \\ ${ }^{2}$ Lecturer of Industrial Technology Fashion Management Study Program-Faculty of Engineering, State University of \\ Malang \\ "Corresponding author,Email: elisunshoe@gmail.com", agushery_um52@yahoo.co.id ${ }^{2}$
}

\begin{abstract}
Facing the industrial revolution 4.0 Human resources (HR) must be well prepared, including graduates of Vocational High Schools (SMK) who are dealing directly with the industrial world. Developing and revitalizing vocational education or vocational schools is one of the efforts to prepare quality human resources. Link and match programs that can be applied to vocational education include cooperation programs with the Business World and the Industrial World, the development of industrial classes, the implementation of apprenticeship teachers (OJT), Internships, and the role of SMK as industrial relations for schools. With the link and match program, we can find out what competencies are most needed by the workforce and what competencies are most needed by the workforce. The purpose of this study is 1) to describe the implementation of the link and match program with the business world and the industrial world of SMK Negeri 3 Blitar graduates, 2) find out the link and match cooperation model that is applied to improve work readiness for SMK Negeri 3 Blitar graduates, 3) know the readiness of HR in SMK 3 Blitar in the face of the industrial revolution 4.0. This research is qualitative research with a case study approach. Data sources used are primary and secondary data sources. Data collection techniques by interview (interview), observation (observation), documents and literature. Data validity testing techniques include the triangulation of technical resources. Data analysis techniques use interactive analysis techniques in the form of data reduction, data presentation, and drawing conclusions/verification.
\end{abstract}

Keywords: human resources, the Industrial World, the Industrial Revolution

\section{INTRODUCTION}

The Industrial Revolution is now entering a new phase that is already in the Industrial 4.0 where this industry is a worldwide production process that combines three important elements, namely humans, machines and robots, and big data (Prasetyo and Sutopo, 2018). The industrial revolution 4.0 has changed the way humans think, live and relate to one another. Significant changes in the fields of technology, economics, social and politics. In this case, it affects human resources (HR) because human resources are one of the success factors of the role of industry 4.0. In improving human resources starting from education, training, guidance for human resources in industry 4.0. The Ministry of Industry has cooperated with 648 industries and 1,862 SMKs with 3,289 cooperation agreements signed. In 2019 vocational education programs that link and match vocational schools are targeted to attract as many as 2,685 vocational schools and 750 companies.
According to Kasali (2018) In the business world and the industrial world, competition faced by vocational graduates is not easy because there is a very rapid change in the industry, even now experiencing a period of disruption. The impact of changes that will occur this century is that industrial competition is not linear, there are several types of jobs because they are replaced by computerized or digital systems. This has become a challenge for young people in the future. Job competencies change and many jobs are threatened with loss. Academic involvement is needed because that of the education system must also be able to adjust in the face of the Industrial Revolution Era 4 (Henning, 2013). Output of SMK graduates' products to be accepted in the job market must be based more on competitive advantage (Abuzar, H.2011)

According to Hendarman,et al. (2016, p. 43) that vocational education or vocational education is necessary emphasizes education that can adjust to (1) market demand (demand-driven); (2) linkages between users of 
education graduates and providers of vocational education; and (3) match between employees (employer) and employers (employer). Measuring the success of the implementation of vocational education is level of quality and relevance, i.e. number of graduates and suitability of the field occupations with areas of expertise (Hendarman, et al. 2016, p. 43).

Education plays an important role in improving human resources. In the revolutionary era, 4.0 human resources (HR) need to improve skills (up-skilling) or renewal of skills (reskilling) based on the needs of the industrial world. Education must reflect the actualization of the potential maintained to be utilized in everyday life. The vocational education system is an alternative for the fulfillment of Indonesian human resources who have competitiveness in the international labor market. Vocational High School (SMK) is an educational institution that has a vision and mission to prepare a professional workforce.

Vocational education has a strategic role and is expected not only to be able to produce a middle-class workforce but also as the development of a center of excellence and strengthening the capabilities of human resources and science and technology. The design of vocational education in vocational schools must be relevant and lead to vocational education that can produce professional staff who have the competence and skills to meet the demands of the Business and Industrial World. The importance of the relevance of education to DU / DI and the labor market is that SMKs can produce superior middle human resources in the areas of expertise required by DU / DI or can create their jobs which can then absorb the existing workforce. According to Hrmo et al (2016), vocational education provides a significant contribution to economic competitiveness and prosperity in a global knowledge-based economy, so it is necessary to pay attention to the needs of the world of work and cooperation between the organizing institutions.

In improving the quality of SMK graduates there needs to be an alignment program between SMK and DUDI. The alignment program in question is the alignment of the supply side and the demand side. Alignment of the supply side is an effort to adjust graduates produced by the world of education with the needs of the world of work which is represented through the level of labor absorption while the alignment of the demand side is represented through the level of fulfillment of the demand for the world of work (Teaching Team for the Education and Work World, 2010).

This concept is known as Link and Match. Link is a situation where education has a functional relationship with market needs, both seen from the concept, wisdom, planning, and implementation of its programs. Match is a situation where programs are developed, fostered, and implemented in the national education system so that it can produce graduates who are in accordance with DUDI needs in terms of the number, type, and quality of graduates required by the world of work. The link and match program is an effort to bridge labor competencies with industry. Real examples of the link and match program are collaboration programs with the business world and the industrial world, the development of industrial classes, the implementation of apprenticeship teachers (OJT), as a link between industry and as a link between industry and alliance schools

\section{Collaboration with the Business World and the Industrial World}

The form of cooperation between the world of education and the world of industry in developing the concept of education can be initiated by harmonizing and developing continuous communication of the conditions and developments of the industry and the needs of industry competencies to be adapted to the educational program at the Vocational School, so that students obtain sufficient and adequate provisions to be able to compete to the world of work. Collaboration with the business world and the industrial world is important to do because the results of education in schools are collective results with the elements of the stakeholders or stakeholders. The form of cooperation is adjusted to the conditions and needs of the school and also related parties that are its partners.

The cooperation of SMKs with the Business World and the Industrial World in enhancing human resources in the 4.0 revolution era is the development of industrial classes, the implementation of apprenticeship teachers (OJT), Internships, and the role of SMKs as industrial relations for schools. In implementing it, the Vocational School collaborates with the business world and the industrial world by conducting: 1) content validation where the learning material covered in the curriculum structure is in accordance with industry needs, 2) Industry visit is an activity carried out to provide insight to students according to their field of expertise, 3) Teachers guest, aims to provide an overview of the company and help implement school learning to match industry demands.

In learning utilization, other staff outside the teacher who teaches at the school are known as the Teacher method guest. The Guest Teacher Method is intended to be an outsider (not a teacher) giving lessons to students following their expertise and skills. The learning method of Resources Person (Guest Teacher) is based on learning based on resources (resources based learning). Sagala (2006: 25) is all forms direct learning confronts students with one several learning resources individually or in groups with all learning activities related to that, so it's not the conventional way where the teacher presents the material to students, but each component can provide information such as libraries, laboratories, gardens, and the like are also learning resources.

\section{Formation of Industrial Class}

According to Aji, Yoto, and Widiyati (2017), the industrial class is a collaboration program between industry and vocational education units in integrating learning in schools with the industrial world. The industrial class aims to (1) produce a quality workforce that is workers who have a level of knowledge, skills and work ethic that are in accordance with the demands of the job, (2) strengthen the linkages and equivalence between Vocational High Schools (SMK) and the labor market, (3 ) increasing the effectiveness and efficiency of the quality education and training process for qualified 
personnel, (4) recognizing and appreciating work experience as part of the education process (Pakpahan, 2002).

The focus in planning this industry class is specificity in increasing student vocational competence. Graduates in class this specialty is expected to have competencies that are ready for work and as needed industry. All activities to be carried out in industrial class are regulated in memorandum of understanding between schools and industry partners. All activities the planning carried out in line with the recommendation statement Chan's research (2006) suggests that vocational education planners focus on new goals the individual work needs of students with satisfaction and improve the design process of learning programs to increase power competitiveness of educational institutions.

\section{Implementation of Internship Teachers (OJT)}

Teacher internships can increase the relevance of productive teacher expertise competencies with the development of science and technology in the business world and the industrial world. Teachers can see clearly, what kind of graduates are sought after and needed by the industry later.

The internship priority for vocational productive teachers is an educational innovation to improve the professionalism of productive vocational teachers in carrying out their duties in introducing a work climate and aligning competency standards in accordance with the demands of the business world and industry. Teacher internships are expected to bridge the gap between learning in vocational schools and the demands of the world of work in the business / industrial world. Through apprenticeship teachers or apprenticeship teachers especially for productive teachers in vocational high schools that are designed with DUDI, because historically according to Evans \& Edwin (1978, p. 36) that "vocational education is actually a development of work training (on the job training) and apprenticeship patterns (apprenticeship) ".

Teacher internships are implemented in the form of; 1) attend work training in industry, 2) internships in industry to produce product and service quality tests in realizing teaching factory agreements, 3) internships in industries to produce teaching factory raw materials, 4) follow internships in industry with the aim of cooperation in order obtaining licenses, 5) attending training to get certification from industry or certification bodies, and 6) following a work apprenticeship to establish cooperation with industry.

\section{Industrial Work Practices}

The development of science and technology (science and technology) in the business world and industry often runs faster than the development of science and technology in vocational schools, causing competency skills taught in vocational schools often experience gaps with the competencies needed by the business and industrial world so that vocational graduates have not ready to work when they graduate. To overcome this gap, industrial work practices are one step so that students get work experience that is by following industry work standards. The involvement of the industry as a place of practice of students is one solution to reduce disparities that occur to be able to create vocational graduates' work skills that are adaptive to the world of work. Internship activities provide opportunities for students to gain skills not obtained in school and provide knowledge of industrial development.

The prakerin definition according to (Dikmenjur: 2008) is as follows, Industrial work practice is a pattern of organizing education and training that is managed jointly between SMKs and industry / professional associations as partner institutions, starting from the planning, implementation, to evaluation and certification stages which constitute a unified program using various alternative forms of implementation, such as day releases, block releases, and so onll. Implementation of the day release according to Wena (2006: 228), during one week of study time will be used several days at school and several days in the industry, depending on the agreement between the school and the industry. While learning time in the implementation of Industrial Work Practices using block releases is divided into months or semesters. This means that the learning process is carried out at school several months or semesters continuously, then in the next month or semester study in the industry.

\section{The Role of Vocational Schools as a Link Between Industry and Vocational Schools}

Small-scale SMKs can join referral schools to share about school management, learning models, learning materials, collaboration with the business and industrial world, practice places for students, employee recruitment by companies, workshop facilities, lab workshops. Referring to the Minister of Education and Culture Regulation Number 22 Year 2015 concerning the Ministry of Education and Culture 2015-2019 strategic plan, among others, states that each district /city must have at least 1 Reference Vocational School. In the process of fostering it needs to be done on an ongoing basis in order to achieve the profile or performance of the Reference Vocational School as a Vocational School that has superior performance, large and effective access in managing the institution, besides the Reference Vocational School must also share the resources of its alliance Vocational School so that it can support the improvement program and equal distribution of Vocational Quality throughout Indonesia.

\section{METHOD}

This research is qualitative research with a case study approach. The data source used is a primary data source that is data obtained from the first source or directly obtained at the study site, namely, in SMK 3 Blitar and secondary data is data obtained not from the first party but certain parties related to this research. Data collection techniques by interview (interview), observation (observation), documents and literature. This research was conducted at Blitar State Vocational School 3 which is a Tourism Vocational School and has received a revitalization program and is a Reference Vocational 
School. Informants or subjects who can provide information in research include Deputy Principal of Public Relations, Deputy Principal for Curriculum, Chairman of the Prakerin Working Group, Chair of the BKK Working Group. Data validity testing techniques include the triangulation of technical resources. Data analysis techniques use interactive analysis techniques in the form of data reduction, data presentation, and drawing conclusions and verification.

Small-scale SMKs can join referral schools to share about school management, learning models, learning materials, collaboration with the business and industrial world, practice places for students, employee recruitment by companies, workshop facilities, lab workshops. Referring to the Minister of Education and Culture Regulation Number 22 Year 2015 concerning the Ministry of Education and Culture Strategic Plan 20152019 in which one of the programs states that each Regency / City has a minimum of 1 Reference / Model Middle Schoolational education (Vocational), the orientation of education must be directed to the needs of the world of work or industry with a sustainable partnership approach.Small-scale SMKs can join referral schools to share about school management, learning models, learning materials, collaboration with the business and industrial world, practice places for students, employee recruitment by companies, workshop facilities, lab workshops. Referring to the Minister of Education and Culture Regulation Number 22 Year 2015 concerning the Ministry of Education and Culture Strategic Plan 2015-2019 in which one of the programs states that each Regency / City has a minimum of 1 Reference / Model Middle Schoolational education (Vocational), the orientation of education must be directed to the needs of the world of work or industry with a sustainable partnership approach.

\section{RESULTS AND DISCUSSION}

Blitar State Vocational School 3 is a vocational school in the tourism and arts family. The school address at Jl. S. Supriyadi 24, Blitar is a school that receives revitalization assistance and is a reference school. SMK 3 Blitar has 5 majors, namely Hospitality Accommodation, Clothing, Catering, Skin and Hair Beauty, Wooden Crafts and Rattan Creations.

Good cooperation and mutual benefits are very important to support the achievement of school programs. School development will be more optimal if collaboration with relevant business and industry institutions with expertise competencies is contained in the MOU / memorandum and cooperation agreement text. The concept of link and match can be implemented well if the three components must move simultaneously to improve the quality of SMK. The three components are SMK, business and industry, and government. In this case, the role of SMK is very important. Vocational Schools must be observant in understanding the needs of the industry and applying it in learning. Besides, vocational schools must also be able to predict and analyze what skills competencies are needed in the future work world.
The results of the study are in line with the theory put forward by (Abuzar.H, 2011) which says that SMKs with the business world through link and match as a form of partnership can benefit; a) Students can directly see how the role of technology in the business world so that after graduating they will no longer be awkward in interacting with the technological process in the business and industrial world, b) Motivating SMK students to create better, in the sense that they can find innovations innovation because it has seen firsthand, c) Able to improve the quality of vocational graduates because in the business world the most important thing is discipline so that it can continue to survive, d) It is easier to design competency-based curriculum because it directly meets the demands of the industry, e) Forms of recruitment labor is not too difficult.

The link and match collaboration model that is applied to improve work readiness for graduates of SMK 3 Blitar include collaborating with businesses and industries where the implementation of the collaboration is in the form of validating curriculum content that is tailored to the needs of the world of work. The industries that are a partner of SMK 3 Blitar to synchronize the curriculum include Andy Sugix and Ayu Busono. The form of collaboration between SMK 3 Blitar and industry is by making an $\mathrm{MoU}$ whose contents are by following the agreed field of cooperation.

Furthermore, the collaborative model undertaken is to conduct industry visits as an insight into the world of work directly. This industrial visit program is one of the educational programs that seek to shape future generations to get to know the industrial culture, carry out work discipline as well as get to know the manufacturing industry. Those who take part in industrial visit activities have analytical and engineering skills that are creative, innovative and independent, have a high level of personality and scientific integrity and have the motivation to follow technological and scientific developments. The industry visit activity is a routine agenda every year for class X students in the even semester. Industry visits carried out at PT. Sri Redjeki Isman (SRITEX) Sukoharjo, Central Java.

Periodically SMK Negeri 3 Blitar invites guest teachers 2 times a year where guest teachers come from one of the DUDI as motivators when training in an internship before students depart internship. Apart from DUDI, successful alumni are also invited as guest teachers in entrepreneurship classes to motivate students to be successful.

When viewed from the pattern of life skills implementation according to the Ministry of National Education in Syafriadi (2017), vocational education is said to be successful in creating graduates with the following indicators of success; 1) Graduates work in accordance with their fields, 2) The grace period of the graduate is a maximum of one year after graduation, 3) The absorption of graduates is at least $75 \%$, 4) The number of graduates who create jobs is $5 \%$. These four indicators can be implemented by SMK Negeri 3 Blitar, especially the Department of Clothing to produce graduates by the following employment. Based on the results of research and interviews with the chairperson of 
the BKK Working Group, it was found that graduates of Dressing 2018/2019 obtained $81.25 \%$ of work data and $14.58 \%$ continued at a higher level. And $70 \%$ work in a field that matches the acquired competency expertise. The data is obtained within 3 months after the graduation of students. After tracing more in the number of students who have their businesses as much as $10 \%$. So that, in this case, SMK Blitar 3 can be declared to have successfully implemented life skills.

In addition to cooperation with the business world and the industrial world, the efforts made by SMKN 3 Blitar in link and match with industry are the implementation of internship teachers. Teacher internships can make the competency the relevance of teacher expertise. This internship program is expected to be able to see the correct work procedures, the required skills and knowledge gained, and experience in the industry which can then be transformed into the student press Teachers who have implemented teacher internships for the expertise and program.

Industrial work practices are a form of link and match program. Internship is part of the learning program that must be taken by every student in the world of work. This is a manifestation of the implementation of Dual System Education (PSG). The apprenticeship program is arranged jointly between the school and the business world and the industrial world to meet the learning needs of students and as a contribution of the business world and the industrial world to the development of vocational education programs. The number of industries that are partners in industrial work practices for fashion expertise programs is 23 industries spread across Blitar, Tulungagung, Malang and Surabaya. The industry is engaged in the field of fashion such as fashion, convection, and designer. In SMK 3 Blitar, it applies the internship program

In addition to infrastructure, the fulfillment of human resources is an appropriate step in facing the revolution era 4.0. Increasing the capacity of human resources must be done because, in the 4.0 revolution era, the development of technology will shift human labor with automation. In the face of the 4.0 revolution there are at least three things that need to be considered, namely efforts made to produce quality human resources, competent and in accordance with the needs of digital technology-based industries, the second is by producing a number of qualified, competent and appropriate industrial needs, third distribution of human resources.

Industry (DUDI) in the Industrial 4.0 era. to prepare human resources who are ready to face the industrial revolution 4.0 there needs to be an increase in cooperation with industry. In the field of marketing, the school provides marketplace workshops as a form of collaboration with various parties. Online product marketing has now been massively carried out by many businesses, both through social media, websites and online marketplaces. In this way, vocational students can promote products through the marketplace so that it is more effective and has a high selling value.

The pattern of cooperation in the Distribution Program for graduates is the spearhead of the entire program, because this will be the benchmark of success in the final process of learning activities with the expectation that all outputs become outcomes, one of the efforts undertaken is by collaborating industry partnerships in the process of graduate recruitment, this must be done with the initiative of the school to deliver data and competencies from graduates and can provide assurance that graduates who will be distributed have adequate competence and are in accordance with industry requirements, both in Knowledge Skills and Attitude. The role of the BKK working group in the preparation of graduates is to hold workshops and seminars by following the readiness to face the challenges of the world of work in the industrial revolution era 4.0 by bringing competent presenters in the fashion industry.

The model or form of cooperation between SMK and industry can be described as follows:

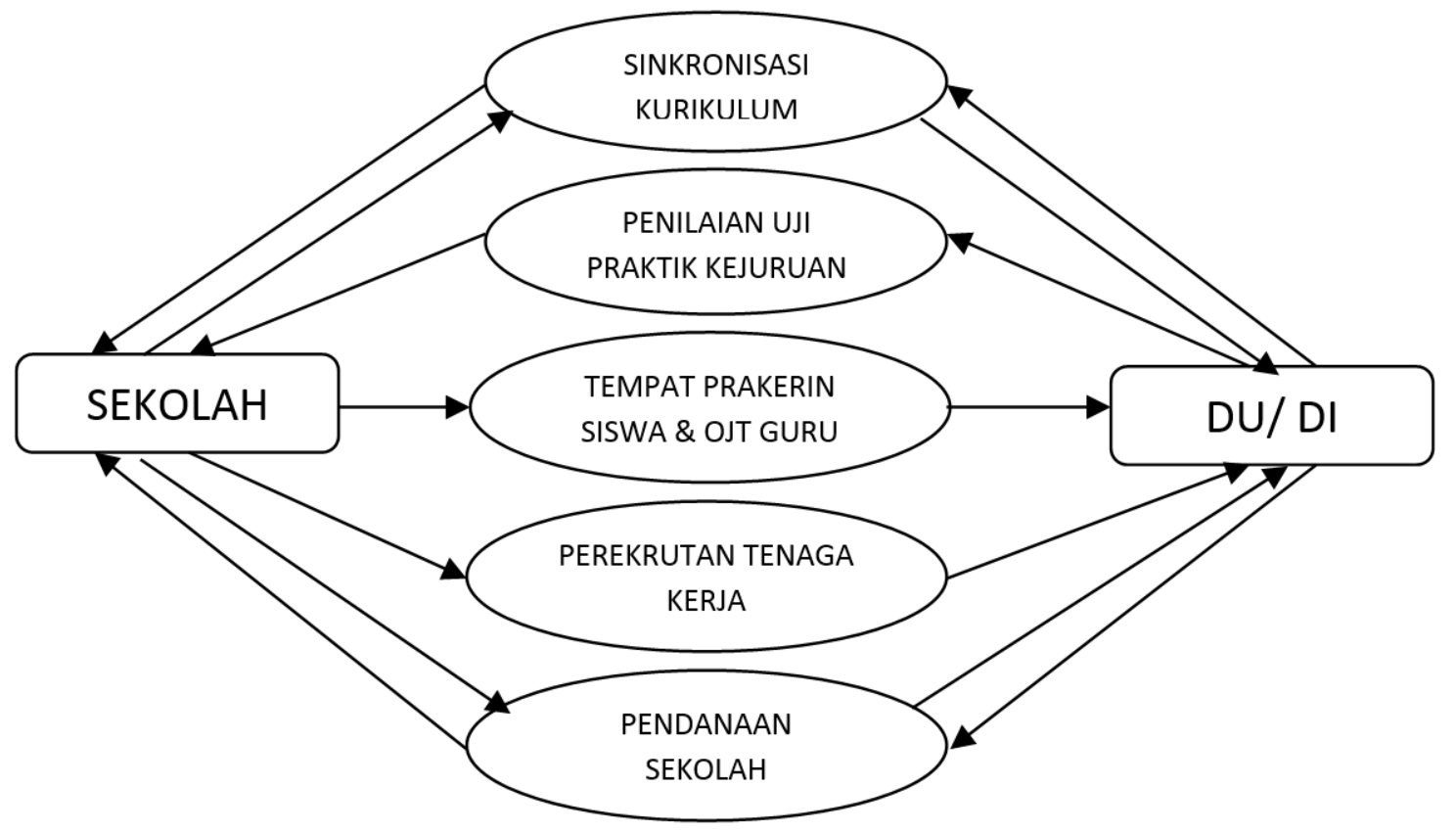


Figure 1. Model Or Form Of Cooperation Between SMK And Industry

\section{CONCLUSION}

Based on the results of research and discussion about the cooperation of Blitar SMK3 with the business world and the industrial world as an effort to increase human resources in the industrial revolution era 4.0:

1. As a vocational education (Vocational), the orientation of education must be directed to the needs of the world of work or industry with a sustainable partnership approach.

2. Forms of cooperation in SMKN 3 Blitar conducted in support of cooperation with the business world and the industrial world; a) Formation of workgroups (Pokja) that handles the implementation of cooperation with DUDI, namely the working group and the BKK working group under the coordination line of the vice principal of public relations b) Proactive schools establish communication with DUDI in promoting the existence of schools, namely the annual event organized by SMKN 3 Blitar. Blitar Food and Fashion Festival (B2F3) where DUDI also participates in the achievement of these activities, c) Schools submit proposals to industries related to school collaboration which includes (synchronization of curriculum, industrial work practices, placement of graduates, OJT of teachers ), d) Utilizing certain roles of DUDI as a guest teacher, e) DUDI cooperating is outlined in the form of a cooperation document or MoU, f) Increasing DUDI cooperation in the provision of job vacancies where BKK working groups hold mini job fair activities attended by industry providing job vacancies work, other than that, SMKN 3 Blitar is also a center for industrial recruitment in recruiting in the city of Blitar as one of BKK's work programs.

3. Increased cooperation with the industrial world in the form of industrial classes in SMK Negeri 3 Blitar. The Fashionable Expertise Competency is still unable to be implemented because the expertise. There needs to be optimization in the implementation of industrial classes as a place for students to grow their skills following industry needs so that students can be directly recruited by companies

4. There needs to be an increase in the teacher internship program because there are still a small number of fashion teachers who have done an internship. Lack of teacher interest in doing an internship due to limited time and money. Teachers who carry out apprenticeships are less optimal in doing so, so the results obtained are also less than optimal.

5. Factors that influence in establishing a cooperative relationship between SMK Negeri 3 Blitar and DU / DI, namely factors from within the organization (internal) and some from outside the organization (external). The factors originating from within the vocational organization itself (internal): namely the joint commitment of school personnel in the delegation of tasks, the availability of reliable human resources and workshops for practice. While factors originating from outside the vocational organization (external): Establishing a cooperative relationship with parents, school committees, the government so that schools can foster cooperative relations with the World of Business World Industry (DU / DI).

\section{REFERENCES}

[1] Apriliyadi. Bersama Kemenprin, SMK Hadapi Revolusi Industri 4.0. 2019. http://portal.ditpsmk.net/konten/4130/bersa ma-kemenperin-smk-hadapi-revolusiindustri-40

[2] Direktorat Pembinaan Sekolah Menengah Kejuruan Direktorat Pendidikan Dasar dan Menengah Kementrian Pendidikan dan Kebudayaan RI. Supervisor Industri Sebagai Guru Tamu di SMK. 2017

[3] Disas, Eka Prihatin. Link and Match Sebagai Kebijakan Pendidikan Kejuruan. Universitas Pendidikan Indonesia. 2018. Jakarta

[4] Fauzan, Muhamad. Magang Guru Antara Kewajiban Formal dan Kewajiban Substansial.

http://fauzanmohamad.gurusiana.id/article/m agang-guru-antara-kewajiban-formal-dankewajiban-substnasi-1474044

[5] Hadam,Sampun, dkk. 10 Langkah Revitalisasi SMK. Direktorat Pembinaan Sekolah Menengah Kejuruan. 2018. Jakarta

[6] Ixtiarto, Bambang dan Sutrisno, Budi. Kemitraan Sekolah Menengah Kejuruan Dengan Dunia Usaha dan Dunia Industri (Kajian Aspek Pengelolaan Pada SMK Muhammadiyah 2 Wuryanto, Kabupaten Wonogiri). Jurnal Pendidikan Ilmu Sosial. Vol 26, No.1, Juni 2016. ISSN:14-12-3835.

[7] Nofindra,Rudi. Magang Guru dan Kompetensi Siswa. http://psmk.kemdikbud.go.id/konten/1743/ma gang-guru-dan-kompetensi-siswa

[8] Perdana, Novrian Satria. Optimalisas Keseimbangan Pasar Tenaga Kerja Lulusan SMK. Jurnal Ilmiah Kependidikan, Volume 9, Nomor 2, Juni 2019, hlm 172-181

[9] Revitalisasi Pendidikan Vokasi. Kementrian Pendidikan dan Kebudayaan. 2016

[10] Rezasyah, Teuku, dkk.Kesiapan Siswa SMK dalam Revolusi Industri 4.0. Departemen Hubungan Internasional, Fakultas Ilmu Sosial dan Ilmu Politik, Universitas Padjadjaran. Jurnal Pengabdian Kepada Mayarakat. Kumawula, Vol. 1, No.2, Agustus 2018, Hal 114 - 119

[11] Soesilowati, Endang.S. Link and Match Dunia Pendidikan dan Industri Dalam 
Meningkatkan Daya Saing Tenaga Kerja dan Industri. Pusat Penelitian Ekonomi Lembaga Ilmu Pengetahuan Indonesia.2009.Jakarta

[12] Sriwardani, Nyenyep. Pola Pembelajaran Model Prakerin Untuk Membangun Kesiapan Memasuki Dunia Kerja. Universitas Sebelas Maret. Prosiding Seminar Nasional Inovasi Pendidikan Inovasi Pembelajaran Berbasis Karakter dalam Menghadapi Masyarakat Ekonomi ASEAN.
[13] Styani, Eka. Manajemen Kerjasama Sekolah Dengan Dunia Usaha dan dunia Industri Dalam Meningkatkan Kompetensi Siswa. Institut Agama Islam Negeri Tulungagung. Thesis. 2018

[14] Usep. Pengelolaan Magang Guru Produktif SMK Paket Keahlian Teknik Sepeda Motor Berbasis Kemitraan. Jurnal Administrasi Pendidikan Vol.XXIV No.1 April 2017

[15] Wahyudi, Arif Susanto. Poli Kemitraan Work Based Learning di SMK N 2 Purworejo. Jurnal Pendidikan Teknik Otomotif Universitas Muhammadiyah. 